\begin{tabular}{c} 
International Journal of Engineering \& Technology, $7(3)(2018) 1495-1500$ \\
International Journal of Engineering \& Technology \\
SPC \\
Website: $\begin{array}{c}\text { ww. sciencepubco.com/index.php/IJET } \\
\text { doi: } 10.14419 / \text { ijet.v7i3.14326 } \\
\text { Research paper }\end{array}$ \\
\hline
\end{tabular}

\title{
Map of Jordan governorates wind distribution and mean power density
}

\author{
Saad S. Alrwashdeh* \\ Mechanical Engineering Department, Faculty of Engineering, Mutah University, P.O Box 7, Al-Karak 61710 Jordan
}

\begin{abstract}
The Renewable energy potential in Jordan is enormous as it lies within the top of the world countries renewable resources. Electricity demand in Jordan plays a major role in the high amount of energy requring to cover the needs of heating, cooling, lighting, etc. For that, the availability of the wind distribution information becomes essential to help in the design and building of the wind energy application. In this study, a wind distribution map is provided of all Jordan governorates: Irbid, Mafraq, Ajloun, Jarash, Amman, Zarqa, Madaba, Balqa, Karak, Tafilah, Mann and Aqaba.
\end{abstract}

Keywords: Renewable energy; Wind distribution; Electricity demand; Jordan governorates.

\section{Introduction}

Recently, energy has a major role in the establishment of wealth and a key issue factor in economic stabilization [1-15]. The energy demand of the world is sharply increasing with the increasing of world population, urbanization and modernization and is expected to keep rising over the coming years [16-20]. Energy consumption of developed countries grows at a rate of approximately $1.5 \%$ per year, and at a rate of 5\% per year in developing countries [21-23]. The future demand for electricity needs shows that the world's electricity consumption is expected almost to double [24-30].

Currently, Wind energy is popularly used in many countries such as the USA, Germany, Spain, China, India, UK, Denmark and Canada. The cumulative global wind energy generating capacity topped $147 \mathrm{GW}$ in 2008 , with an increase of about $80 \%$ of new capacity that were installed worldwide during the past decade, according to preliminary estimates by the American Wind Energy Association (AWEA) and the European Wind Energy Association (EWEA). Global wind power generating capacity has been duplicated around five times from $31.128 \mathrm{GW}$ in 2002 to reach over than $147 \mathrm{GW}$ at the end of 2008 [31-35].

Jordan, on the other hand, is a country of sun and wind. However, until recently, energy sources used were exclusively oil and gas fossil energies. It has been so, until the political changes in the Middle East in 2003, where Jordan lived in some sort of energetic comfort; Iraq used to provide Jordan with oil at preferential prices over the 80-90s of last century, while the 60-70s era witnessed support from the gulf in oil support. The interest in wind energy applications in Jordan began in 1979 at Royal Scientific Society (RSS). After the 2003 political changes, oil prices exploded on international markets and Jordan found itself in a difficult situation. To remedy the problem and make the country less vulnerable, the Jordanian government sat up a series of initiatives, and the establishment of a center for research on renewable energies "National Energy Research Center, NERC" is one of the steps undertaken. In addition, the royal scientific society had a department engaged in renewable energies since 1972 . Today, Jordan planned to install more than $20 \%$ of the required energy from the renewable sources especially the solar and wind applications. Tafilah wind project in Jordan provide the national grid with $132 \mathrm{MW}$ of the electricity and some small application all over Jordan provide 25MW electricity from the wend [9], [36-40].

In this study, wind energy distribution has been investigated on all Jordan governorates by using meteorological data provided from the measurement station. The wind characteristics were also studied according to the wind speed, years, and hours of the day. According to the evaluation, wind speed distribution is obtained and the most suitable sites for wind farms are determined.

\section{Wind speed distribution data}

The wind distribution data at Jordan governorates used in this study were obtained from measurements that were made once every seven hours daily for the period of twelve years, (2004-2016) [9]. Twelve governorates were selected in this study; Irbid, Mafraq, Ajloun, Jerash, Balqa, Madaba, Amman, Zarqa, Karak, Tafilah, Maan and Aqaba. The geographical locations of these stations are shown in figure. 1. All measurements at all the wind observation stations are recorded using a cup anemometer at a height of $10 \mathrm{~m}$ above the ground level. The geographical coordinates of the meteorological stations examined are presented in table 1.

The mean monthly and annual averages of wind speed at a height of $10 \mathrm{~m}$ are listed in table. 2 . The maximum value of monthly mean wind speed of $8 \mathrm{~m} / \mathrm{s}$ is measured at Aqaba governorate in June and a minimum value of $1.8 \mathrm{~m} / \mathrm{s}$ is measured at Balqa governorate in October. Figure. 2 shows the wind speed of all Jordan governorates all over the year. 
Table 1: Geographical Coordinates of Stations for All Jordan Governorates [9]

\begin{tabular}{llll}
\hline Region & Latitude (DEG, N) & Longitude (DEG, E) & Average Elevation $(\mathrm{m})$ \\
\hline Irbid & $33^{\circ}$ & $36^{\circ}$ & 620 \\
Ajloun & $32^{\circ}$ & $36^{\circ}$ & 820 \\
Jarash & $32^{\circ}$ & $36^{\circ}$ & 763 \\
Mafraq & $31^{\circ}$ & $36^{\circ}$ & 700 \\
Amman & $29^{\circ}$ & $35^{\circ}$ & 50 \\
Zarqa & $32^{\circ}$ & $36^{\circ}$ & 619 \\
Balqa & $32^{\circ}$ & $35^{\circ}$ & 820 \\
Madaba & $31^{\circ}$ & $35^{\circ}$ & 763 \\
Tafilah & $30^{\circ}$ & $35^{\circ}$ & 940 \\
Karak & $31^{\circ}$ & $35^{\circ}$ & 930 \\
Maan & $30^{\circ}$ & $35^{\circ}$ & 1100 \\
Aqaba & $30^{\circ}$ & $35^{\circ}$ & 6 \\
\hline
\end{tabular}

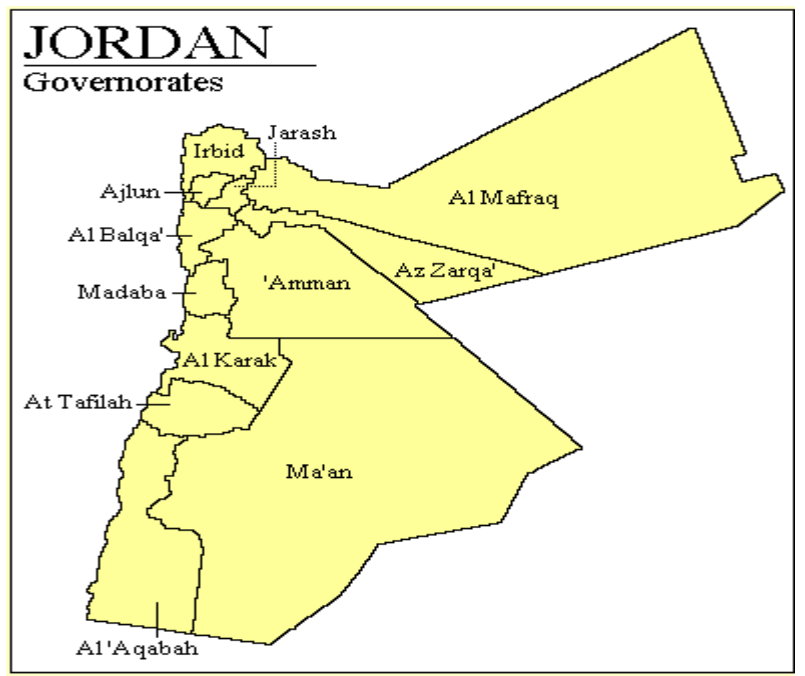

Fig. 1: Jordan Governorates Map.

Table 2: Mean Monthly and Annual Wind Speed (M/S) at Height of $10 \mathrm{M}$ for Jordan Governorates [9]

\begin{tabular}{llllllllllllll}
\hline Month & Irbid & Ajloun & Jarash & Mafraq & Amman & Zarqa & Karak & Balqa & Madaba & Tafilah & Maan & Aqaba \\
\hline January & 2.8 & 2.78 & 3 & 3.5 & 3.3 & 3.1 & 3 & 3.2 & 3 & 2.8 & 5.6 & 6 \\
February & 2.9 & 2.32 & 3 & 3.6 & 3.3 & 3.2 & 3.3 & 3.2 & 3.5 & 2.9 & 5.6 & 6 \\
March & 2.8 & 2.33 & 3.5 & 3.5 & 3.3 & 3.3 & 3.5 & 3.2 & 3.4 & 3.06 & 5.9 & 7 & 7 \\
April & 2.7 & 2.66 & 3.6 & 3.1 & 3.2 & 3.3 & 3.1 & 3.2 & 3 & 3 & 6 & 7 \\
May & 3.09 & 2.51 & 3.5 & 3.4 & 3.3 & 3.1 & 3 & 3.5 & 3.1 & 3.09 & 6.2 & 7 \\
June & 3.32 & 2 & 4 & 4 & 3.4 & 3.9 & 3.8 & 4.2 & 3.5 & 3.78 & 7.1 & 8 \\
July & 4.1 & 1.81 & 4.2 & 4.2 & 4.3 & 3.8 & 4.2 & 4.3 & 3.7 & 4.48 & 7.3 & 7 \\
August & 3.89 & 1.57 & 3.6 & 3.3 & 3.5 & 3.4 & 3.6 & 3 & 3 & 3.89 & 6 & 7 \\
September & 2.6 & 2.17 & 3.4 & 3.4 & 2.1 & 3.2 & 3 & 2.7 & 2.3 & 3.33 & 5.8 & 6.5 \\
October & 2.4 & 1.66 & 3.3 & 3.3 & 2.2 & 3 & 3.2 & 1.8 & 2 & 3 & 5.6 & 7 \\
November & 2 & 3.29 & 3.2 & 3 & 2.1 & 3 & 3 & 1.9 & 2.8 & 2.55 & 5.6 & 6 \\
December & 2 & 2.96 & 3.2 & 3 & 2.4 & 3 & 3 & 2 & 2.65 & 2.57 & 5.4 & 6 \\
Mean Speed & 2.88 & 2.34 & 3.46 & 3.44 & 3.03 & 3.28 & 3.31 & 3.02 & 3.00 & 3.20 & 6.01 & 6.71 \\
\hline
\end{tabular}

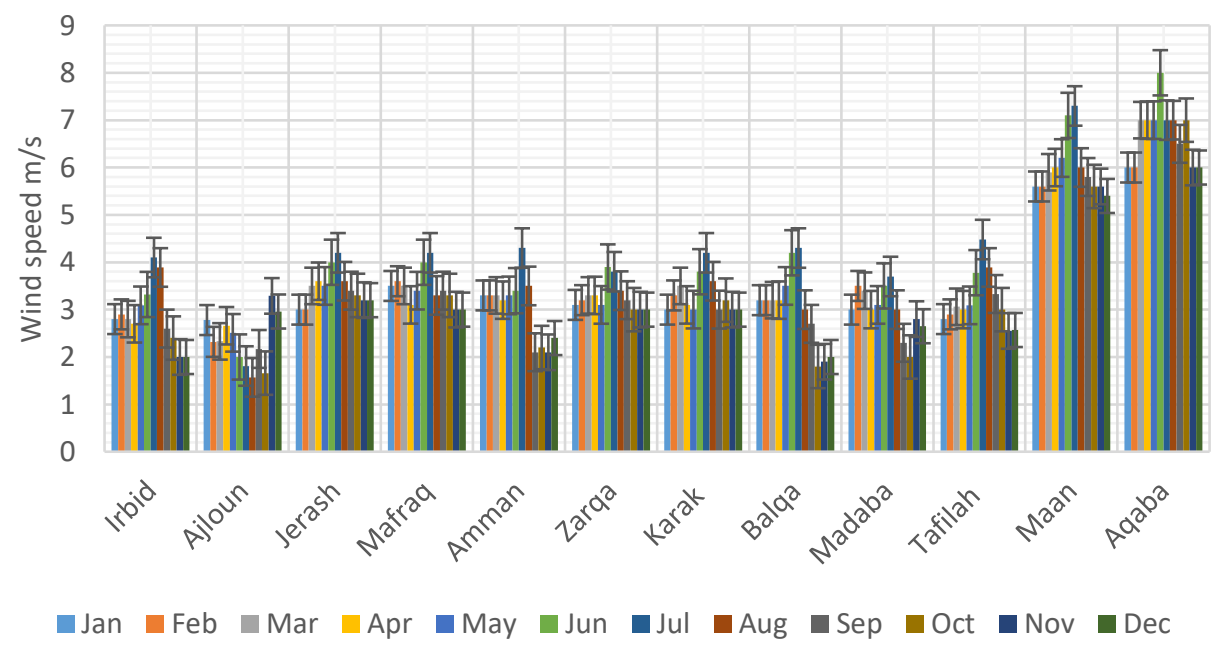

Fig. 2: Mean Monthly Wind Speed Variation for Jordan Governorates. 


\section{Wind power calculation}

The principle of wind power generation can be stated as follows, 'for all wind turbines, wind power is proportional to wind speed cubed.' Since wind energy is the kinetic energy of moving air the kinetic energy of a mass $\mathrm{m}$ with velocity $\mathrm{v}$ is given by [38].

$E_{\text {kinetic }}=12 / m v^{2}$

The air mass $\mathrm{m}$, can be determined from the air density $\rho$, and the air volume $\mathrm{V}$ according to

$m=\rho V$

Then,

$E_{\text {kineti(wind })}=12 / V \rho v^{2}$

Since power is energy divided by time, we consider a small time, $\Delta t$, in which the air particles travel a distance $s=v \Delta t$ to flow through. We multiply the distance with the rotor area of the wind turbine, $A$, resulting in a volume of

$$
\Delta V=A v \Delta t
$$

Which drives the wind turbines for the small period of time. Hence, the wind power is given as

$$
\begin{aligned}
& P_{\text {wind }}=E_{\text {kinetic }(\text { wind })} / \Delta t \\
& =\Delta V \rho v^{2} / 2 \Delta t \\
& =\rho A v^{3} / 2
\end{aligned}
$$
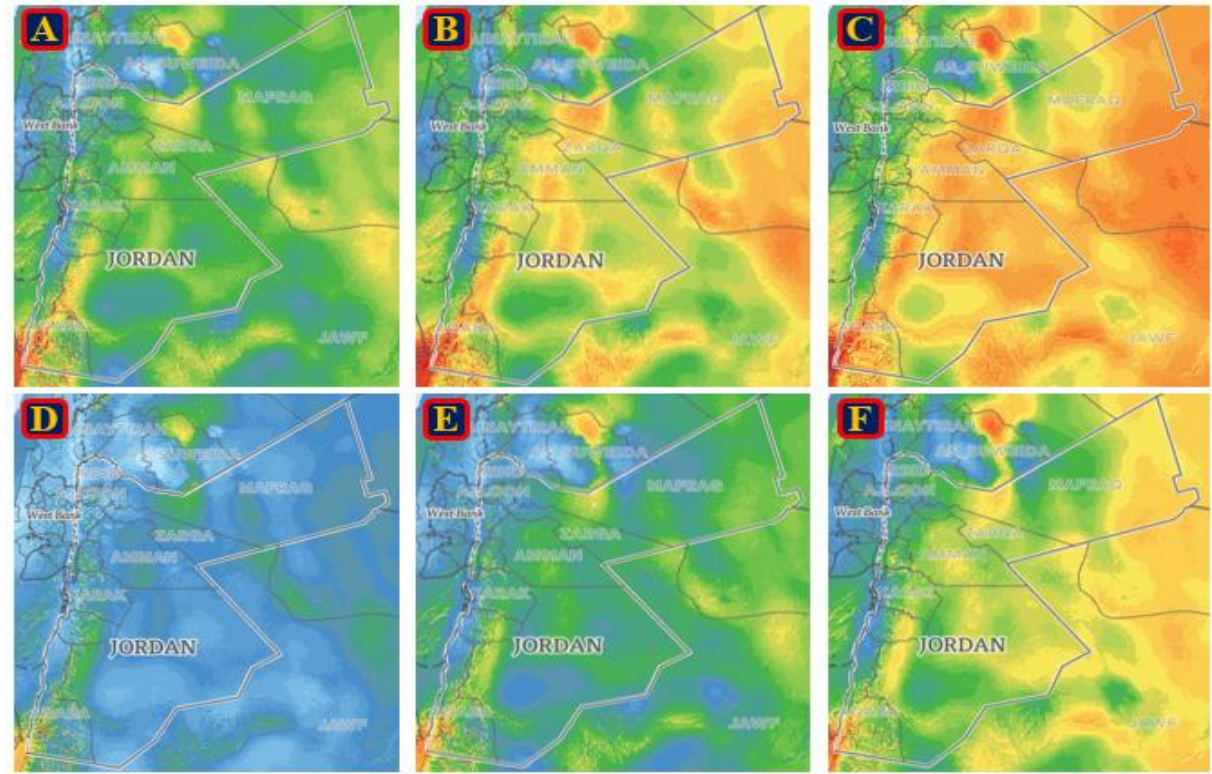

Fig. 3: Wind Speed Distribution and Mean Power Density at 50, 100 and 200m of Jordan.
The variations in wind speed, makes the use of wind speed and air density alone, unreliable for analysis of wind power potential. The Energy Pattern factor method, analyzes these variations and estimates a unique wind power density for each location.

The available mean power density at any location defined as:

$$
P a^{-}=12 \rho v^{-3} \mathrm{Ke}
$$

Where $\bar{v}$ is the mean wind speed and $K e$ is the energy pattern factor

\section{Wind speed distributions}

It is very important for the wind industry to be able to describe the variation of wind speeds. Turbine designers need the information to optimize the design of their turbines, so as to minimize generating costs. Turbine investors need the information to estimate their income from electricity generation. Figure. 2 shows a wind speed distribution in Jordan and the mean power density at different heights of 50, 100 and $200 \mathrm{~m}$ (A, B and C). Based on that it is noted that Jordan come in range from 5.5 to $6.5 \mathrm{~m} / \mathrm{s}$ in term of wind speed distribution at $50 \mathrm{~m}$ height and in range of 6.5 to $7.0 \mathrm{~m} / \mathrm{s}$ at height of $100 \mathrm{~m}$. Finally, in arrange between 7.0 and $8.0 \mathrm{~m} / \mathrm{s}$ at a height of $200 \mathrm{~m}$. The mean power density at heights of 50,100 and $200 \mathrm{~m}$ (D, $\mathrm{E}$ and $\mathrm{f}$ ) with a range from 150 to $200 \mathrm{~W} / \mathrm{m}^{2}$ at $50 \mathrm{~m}$ height, from 250 to $350 \mathrm{~W} / \mathrm{m}^{2}$ at height of $100 \mathrm{~m}$ and between 350 and $600 \mathrm{~W} / \mathrm{m}^{2}$ Analysis of the wind mean power density in Jordan governorates is playing a vital role in the selection of the best governorate to have the maximum benefit from the available resources. Thus, reduction in the investment cost. Figure.4 shows Mean power density of Jordan governorates at 50,100 and $200 \mathrm{~m}$ heights. The mean power density is increased with increasing of the elevation from 50 to 200 $\mathrm{m}$ as it is noted in the figure.4A-L. Aqaba governorate shows a maximum mean power density for the three different heights. 


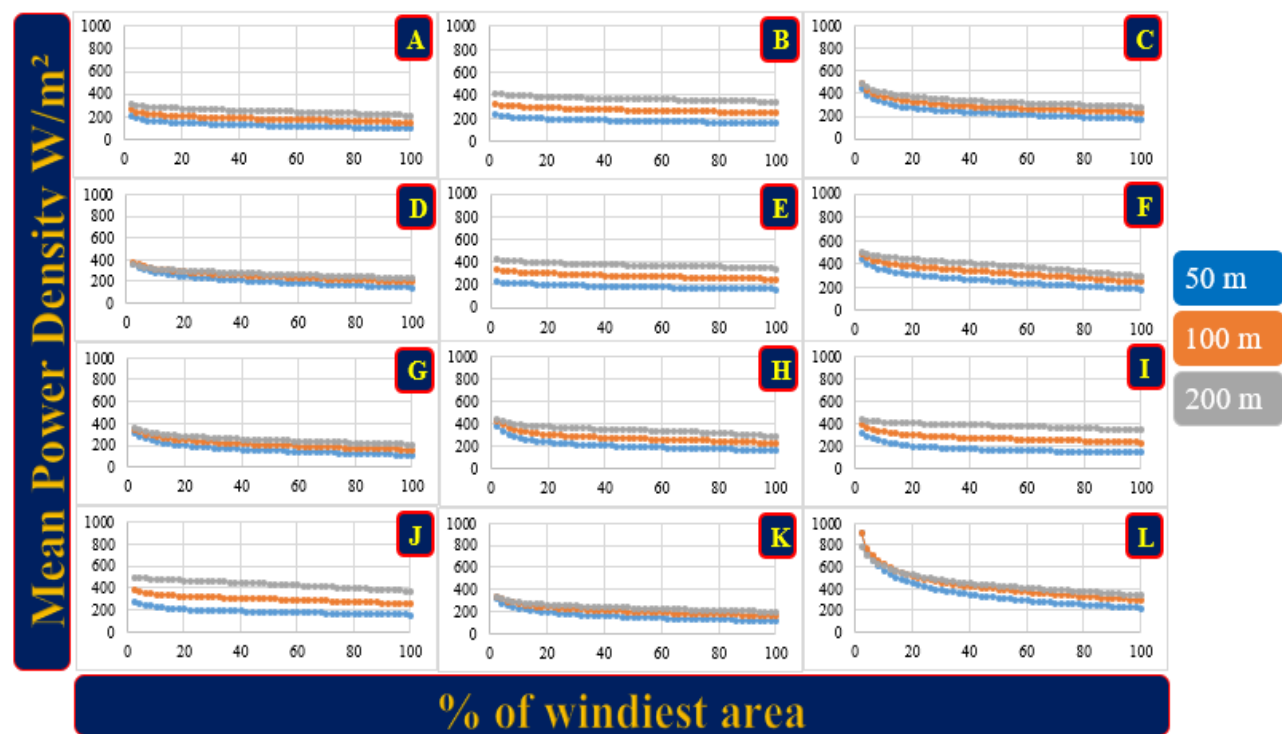

Fig. 4: Mean Power Density At Heights of 50, 100 and $200 \mathrm{M}$ for Each of the Jordan Governorates: Irbid (A), Ajloun (B), Jarash (C), Mafraq (D), Amman (E), Zarqa (F), Karak (G), Balqa(H), Madaba (I), Tafilah (J), Maan (K) and Aqaba (L).

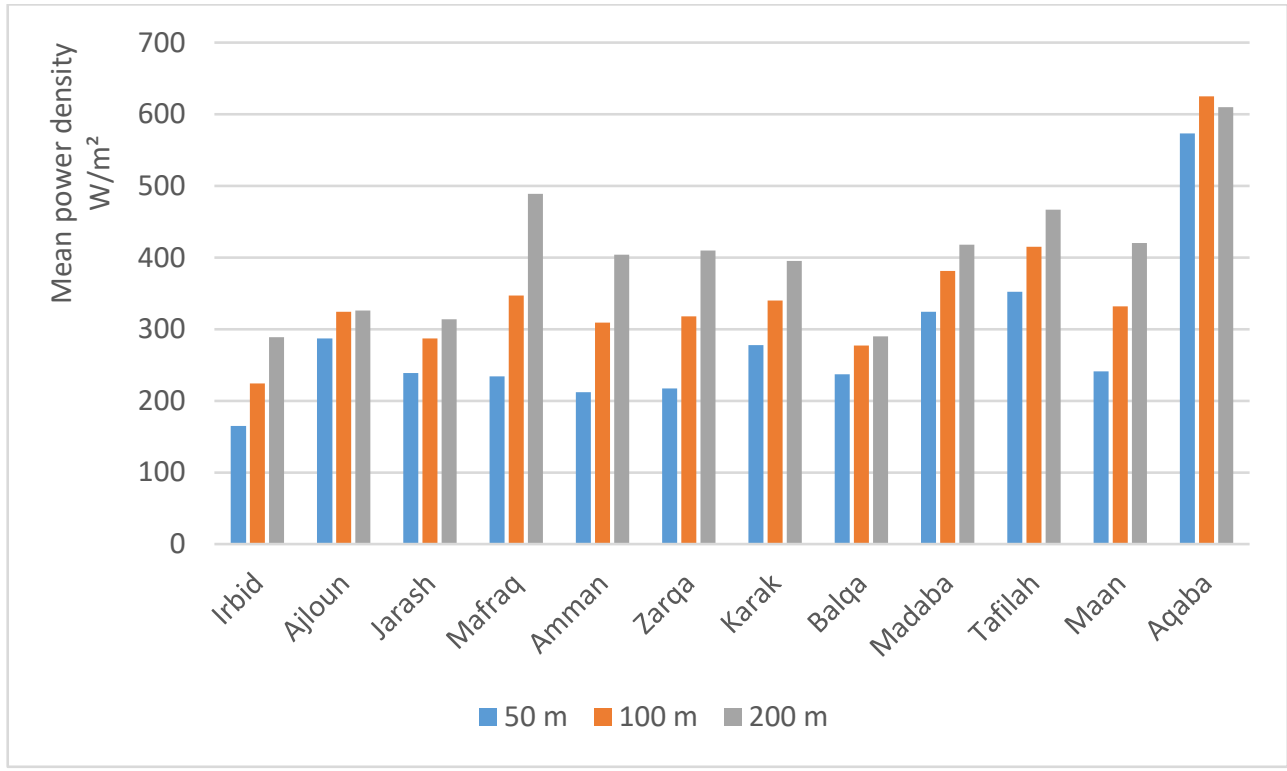

Fig. 5: Mean Power Density of Jordan Governorate at 50, 100 and 200 M Heights
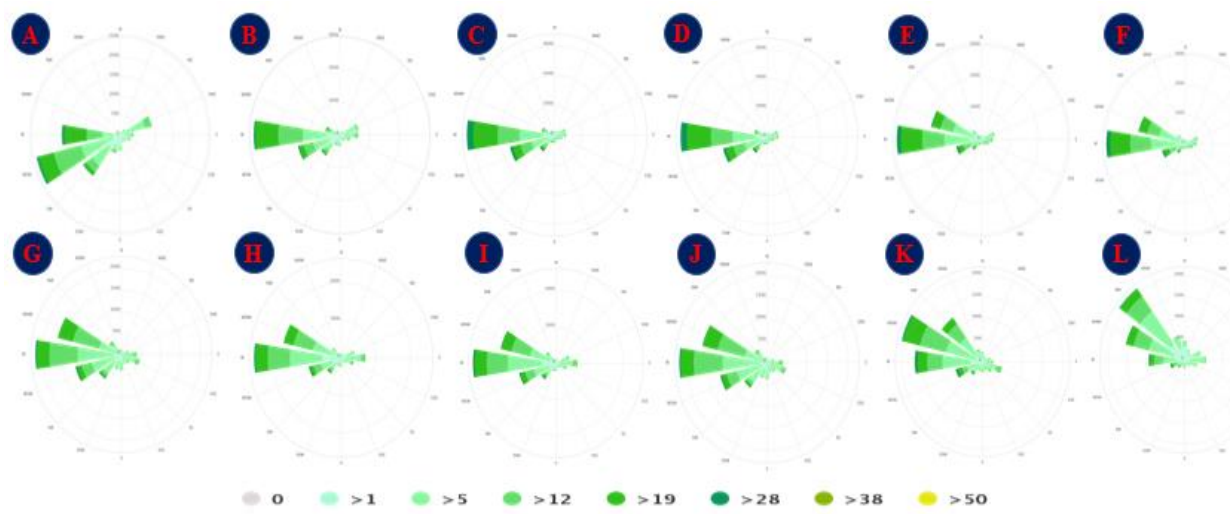

Fig. 6: Jordan Governorates Wide Roses: Irbid (A), Ajloun (B), Jarash (C), Mafraq (D), Amman (E), Zarqa (F), Karak (G), Balqa (H), Madaba (I), Tafilah $(\mathrm{J})$, Maan $(\mathrm{K})$ and Aqaba (L).

Figure. 5 shows the mean power density at different heights 50,100 and $200 \mathrm{~m}$ with a using of $10 \%$ from the windiest area. It is noted that a possible mean power density achievement of $600 \mathrm{~W} / \mathrm{m}^{2}$ in the average by using Aqaba governorate as a wind site for a wind energy investment. Irbid has the lowest wind mean power density with an average of $200 \mathrm{~W} / \mathrm{m}^{2}$. The mean power density is increased toward the south governorates of Jordan until the maximum in Aqaba governorate the farthest south of Jordan. In the middle governorates of Jordan, the mean power density is within an average of 350 $\mathrm{W} / \mathrm{m}^{2}$.

The wind rose shows how many hours per year the wind blows from the indicated direction. Example SW: Wind is blowing from SouthWest (SW) to North-East (NE). Figure. 6 shows the wind roses of 
Jordan governorates. It is noted that the majority of the wind in Aqaba and Maan governorates which are the highest in the production of the mean power density in the NW direction. Ajloun, Jarash, Mafraq, Amman, Zarqa, Karak, Balqa, Madaba and Tafilah wind distribution direction is toward W. Irbid governorate wind distribution in the direction of WSW.

\section{Conclusion}

Assessments of the wind distribution and wind mean power density in Jordan governorates using mathematical and world wind atlas were made.

The following conclusions can be drawn from the results of this study:

- The maximum value of monthly wind speed is determined at Aqaba governorate and the minimum value is at Al-Salt governorate.

- The maximum mean power density at the three selected heights was in Aqaba governorate.

- The mean power density is increased toward the south governorates.

- Depending on the wind distribution mapping, it is noted that a wind energy investment will play a major role in the covering of the electricity demand of Jordan.

\section{References}

[1] Urpelainen, J., RISE to the occasion? A critique of the World Bank's Regulatory Indicators for Sustainable Energy. Energy Research \& Social Science, 2018. 39: p. 69-73. https://doi.org/10.1016/j.erss.2017.10.034.

[2] Yuan, X., et al., Method for evaluating the real-world driving energy consumptions of electric vehicles. Energy, 2017. 141: p. 1955-1968. https://doi.org/10.1016/j.energy.2017.11.134

[3] Kannan, N. and D. Vakeesan, Solar energy for future world: - A review. Renewable and Sustainable Energy Reviews, 2016. 62: p 1092-1105. https://doi.org/10.1016/j.rser.2016.05.022.

[4] Andreoni, V., Energy Metabolism of 28 World Countries: A Multiscale Integrated Analysis. Ecological Economics, 2017. 142: p. 5669. https://doi.org/10.1016/j.ecolecon.2017.06.021.

[5] Moya, D., et al., Municipal solid waste as a valuable renewable energy resource: a worldwide opportunity of energy recovery by using Waste-To-Energy Technologies. Energy Procedia, 2017. 134 p. 286-295. https://doi.org/10.1016/j.egypro.2017.09.618.

[6] Panos, E., M. Densing, and K. Volkart, Access to electricity in the World Energy Council's global energy scenarios: An outlook for developing regions until 2030. Energy Strategy Reviews, 2016. 9: p 28-49. https://doi.org/10.1016/j.esr.2015.11.003.

[7] Chen, G.Q. and X.F. Wu, Energy overview for globalized world economy: Source, supply chain and sink. Renewable and Sustainable Energy Reviews, 2017. 69: p. 735-749. https://doi.org/10.1016/j.rser.2016.11.151.

[8] Al-Najideen, M.I. and S.S. Alrwashdeh, Design of a solar photovoltaic system to cover the electricity demand for the faculty of Engineering- Mu'tah University in Jordan. Resource-Efficient Technologies, 2017. 3(4): p. 440-445. https://doi.org/10.1016/j.reffit.2017.04.005.

[9] Alsaad, M.A., Wind energy potential in selected areas in Jordan. Energy Conversion and Management, 2013. 65: p. 704-708. https://doi.org/10.1016/j.enconman.2011.12.037.

[10] Saad S. Alrwashdeh, et al., Investigation of Water Transport in Newly Developed Micro Porous Layers for Polymer Electrolyte Membrane Fuel Cells. Applied Microscopy, 2017. 47(3): p. 101-104. https://doi.org/10.9729/AM.2017.47.3.101.

[11] Saad S. Alrwashdeh, et al., Improved Performance of Polymer Electrolyte Membrane Fuel Cells with Modified Microporous Layer Structures. Energy Technology, 2017. 5(9): p. 1612-1618. https://doi.org/10.1002/ente.201700005.

[12] Saad S. Alrwashdeh, e.a., Water Transport Dynamics inside Polymer Electrolyte Membrane Fuel Cells with Highly Porous Microporous Layer, in 229th Electrochemical Society Conference. 2016: CAUSA.

[13] Alrwashdeh, S.S., et al., Investigation of water transport dynamics in polymer electrolyte membrane fuel cells based on high porous micro porous layers. Energy, 2016. 102: p. 161-165. https://doi.org/10.1016/j.energy.2016.02.075.

[14] Alrwashdeh, S.S., et al., Neutron radiographic in operando investigation of water transport in polymer electrolyte membrane fuel cells with channel barriers. Energy Conversion and Management, 2017. 148: p. 604-610. https://doi.org/10.1016/j.enconman.2017.06.032.

[15] Alrwashdeh, S.S., et al., In Operando Quantification of ThreeDimensional Water Distribution in Nanoporous Carbon-Based Layers in Polymer Electrolyte Membrane Fuel Cells. ACS Nano, 2017. 11(6): p. 5944-5949. https://doi.org/10.1021/acsnano.7b01720.

[16] Jradi, M., et al., A World Class Energy Efficient University Building by Danish 2020 Standards. Energy Procedia, 2017. 132: p. 21-26. https://doi.org/10.1016/j.egypro.2017.09.625.

[17] Goldemberg, J. and L.T. Siqueira Prado, The decline of sectorial components of the world's energy intensity. Energy Policy, 2013. 54 p. 62-65. https://doi.org/10.1016/j.enpol.2012.11.023.

[18] Arto, I., et al., The energy requirements of a developed world. Energy for Sustainable Development, 2016. 33: p. 1-13. https://doi.org/10.1016/j.esd.2016.04.001.

[19] Zarrouk, S.J., Postgraduate geothermal energy education worldwide and the New Zealand experience. Geothermics, 2017. 70: p. 173-180. https://doi.org/10.1016/j.geothermics.2017.06.014.

[20] Khatib, H., IEA World Energy Outlook 2011-A comment. Energy Policy, 2012. 48: p. 737-743. https://doi.org/10.1016/j.enpol.2012.06.007.

[21] World Energy Council teams up with World Water Council to focus on water-energy nexus. Pump Industry Analyst, 2014. 2014(3): p. 3 https://doi.org/10.1016/S1359-6128(14)70087-4.

[22] Goldemberg, J. and L.T. Siqueira Prado, The decline of the world's energy intensity. Energy Policy, 2011. 39(3): p. 1802-1805. https://doi.org/10.1016/j.enpol.2011.01.013.

[23] World Future Energy Summit (WFES) 2015. Pump Industry Analyst, 2014. 2014(11): p. 3-4.

[24] Qi, Z., et al., Investigating Real-World Energy Consumption of Electric Vehicles: A Case Study of Shanghai. Procedia Computer Science, 2018. 131: p. 367-376. https://doi.org/10.1016/j.procs.2018.04.176.

[25] Lin, W., R.L. Spore, and E.A. Nephew, Land reclamation and stripmined coal production in appalachia. Journal of Environmental Economics and Management, 1976. 3(3): p. 236-252. https://doi.org/10.1016/0095-0696(76)90023-1.

[26] Srivastava, A., S. Van Passel, and E. Laes, Assessing the success of electricity demand response programs: A meta-analysis. Energy Research \& Social Science, 2018. 40: p. 110-117. https://doi.org/10.1016/i.erss.2017.12.005.

[27] Morley, J., K. Widdicks, and M. Hazas, Digitalisation, energy and data demand: The impact of Internet traffic on overall and peak electricity consumption. Energy Research \& Social Science, 2018. 38: p. 128-137. https://doi.org/10.1016/j.erss.2018.01.018.

[28] Staffell, I. and S. Pfenninger, The increasing impact of weather on electricity supply and demand. Energy, 2018. 145: p. 65-78. https://doi.org/10.1016/j.energy.2017.12.051.

[29] Burke, P.J. and S. Kurniawati, Electricity subsidy reform in Indonesia: Demand-side effects on electricity use. Energy Policy, 2018. 116: p. 410-421. https://doi.org/10.1016/j.enpol.2018.02.018.

[30] Campbell, A., Price and income elasticities of electricity demand: Evidence from Jamaica. Energy Economics, 2018. 69: p. 19-32. https://doi.org/10.1016/j.eneco.2017.10.040.

[31] Rand, J. and B. Hoen, Thirty years of North American wind energy acceptance research: What have we learned? Energy Research \& Social Science, 2017. 29: p. 135-148. https://doi.org/10.1016/j.erss.2017.05.019.

[32] Sahu, B.K., Wind energy developments and policies in China: A short review. Renewable and Sustainable Energy Reviews, 2018. 81 p. 1393-1405. https://doi.org/10.1016/i.rser.2017.05.183.

[33] Willis, D.J., et al., Wind energy research: State-of-the-art and future research directions. Renewable Energy, 2018. 125: p. 133-154. https://doi.org/10.1016/j.renene.2018.02.049.

[34] Thompson, M., et al., Factors associated with bat mortality at wind energy facilities in the United States. Biological Conservation, 2017. 215: p. 241-245. https://doi.org/10.1016/j.biocon.2017.09.014.

[35] Mercer, N., G. Sabau, and A. Klinke, "Wind energy is not an issue for government": Barriers to wind energy development in Newfoundland and Labrador, Canada. Energy Policy, 2017. 108: p. 673-683. https://doi.org/10.1016/j.enpol.2017.06.022.

[36] Khraiwish Dalabeeh, A.S., Techno-economic analysis of wind power generation for selected locations in Jordan. Renewable Energy, $2017 . \quad 101$ : p. 1369-1378. https://doi.org/10.1016/j.renene.2016.10.003. 
[37] Al-omary, M., M. Kaltschmitt, and C. Becker, Electricity system in Jordan: Status \& prospects. Renewable and Sustainable Energy Reviews, 2018. 81: 2398-2409. https://doi.org/10.1016/j.rser.2017.06.046.

[38] Ammari, H.D., S.S. Al-Rwashdeh, and M.I. Al-Najideen, Evaluation of wind energy potential and electricity generation at five locations in Jordan. Sustainable Cities and Society, 2015. 15: p. 135-143. https://doi.org/10.1016/j.scs.2014.11.005.

[39] Bataineh, K.M. and D. Dalalah, Assessment of wind energy potential for selected areas in Jordan. Renewable Energy, 2013. 59: p. 75-81. https://doi.org/10.1016/j.renene.2013.03.034.

[40] Feilat, E.A., S. Azzam, and A. Al-Salaymeh, Impact of large PV and wind power plants on voltage and frequency stability of Jordan's national grid. Sustainable Cities and Society, 2018. 36: p. 257-271. https://doi.org/10.1016/j.scs.2017.10.035. 